\title{
Einladung zur Mitgliederversammlung
} des Vereins Ultraschallmuseum e. V. 2015 in Davos

Sehr geehrte Frau Kollegin, sehr geehrter Herr Kollege,

hiermit lade ich Sie ganz herzlich zu unserer diesjährigen Mitgliederversammlung ein.

Zeitpunkt: Donnerstag, der 24. September 2015, 13-14 Uhr

Ort: Kongresszentrum Davos, während des DLT

Raum: steht im Programmheft bzw am Museumsstand
Tagesordnung

$\nabla$

1. Genehmigung des Protokolls der letzten MV

2. Bericht des Vorsitzenden

3. Finanzbericht, Entlastung

4. Verschiedenes

B. Frentzel-Beyme, Vorsitzender 